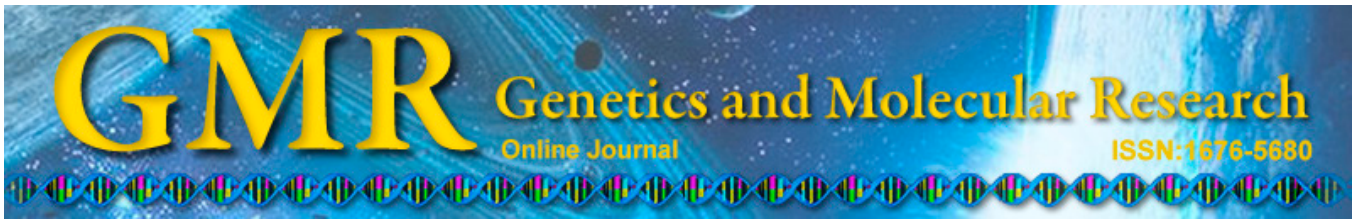

\title{
Differential expression of luteinizing hormone receptor, androgen receptor and heat-shock protein 70 in the testis of long-distance transported mice
}

\author{
L.P. Sun ${ }^{1,2}$, Y.P. Song ${ }^{3}$, J.J. Liu ${ }^{1}$, X.R. Liu ${ }^{1}$, A.Z. Guo ${ }^{3}$ and L.G. Yang ${ }^{1}$ \\ ${ }^{1}$ China Education Ministry's Key Laboratory in Agricultural Animal Genetics, \\ Breeding and Reproduction, Wuhan, China \\ ${ }^{2}$ School of Food and Bioengineering, Zhengzhou University of Light Industry, \\ Zhengzhou, China \\ ${ }^{3}$ The State Key Laboratory of Agricultural Microbiology, \\ Huazhong Agricultural University, Wuhan, China \\ Corresponding author: L.G. Yang \\ E-mail: yangliguo2006@aliyun.com
}

Genet. Mol. Res. 14 (3): 9985-9993 (2015)

Received February 28, 2015

Accepted June 11, 2015

Published August 21, 2015

DOI http://dx.doi.org/10.4238/2015.August.21.4

\begin{abstract}
Spermatogenesis, is a complex process of precisely regulated intracellular events, where it is affected by many factors. Long-distance transport of animals is one of the stressors that may influence spermatogenesis and sperm quality. The present study chose luteinizing hormone receptor (LHR), androgen receptor (AR), and heatshock protein 70 (HSP70) as our target genes to investigate their mRNA and protein expression in the testes of long-distance transported (about $1000 \mathrm{~km}$ ) mice. Histological analysis showed that there was a reduction in the thickness of the seminiferous epithelium in the transported mice, and a significant decrease in body weight and sperm count in the epididymis was also observed. mRNA expression was determined by QPCR in the testis of transported and control mice. The levels for AR
\end{abstract}


decreased significantly in transported mice. LHR and HSP70 expression in the testes of the transported mice was slightly higher than that of control mice but did not reach a significant level. A similar tendency of protein expression was also observed by Western blot analysis. The levels of LHR and HSP70 increased slightly after transportation. However, none of the changes were statistically significant compared with the control mice. In conclusion, long-distance transport has an adverse effect on reproductive organs and spermatozoa in adult mice.

Key words: Transport stress; Male reproduction; Androgen receptor; Luteinizing hormone receptor; Heat-shock protein 70

\section{INTRODUCTION}

With the rapid development of animal husbandry and the emergence of many new dairy farms, transportation has become an unavoidable thing. However, road transportation especially long-distance transportation as a stressor could do much harm to the dairy industry. The economic losses due to transport stress include decreased body weight (Greer et al., 2011; Gonzalez et al., 2012), decreased milk production and changes in meat quality (Honkavaara et al., 2003; Hoffman and Fisher, 2010; Smiecinska et al., 2011) and higher incidence of diseases. Significantly higher egg production of Dicrocoelium dendriticum was observed in the feces of transported ewes (Sotiraki et al., 1999). Transportation stress alters immune function (Riondato et al., 2008; Lv et al., 2011), which further increases the incidence of respiratory diseases (Sporer et al., 2008). Significantly decreased mean total serum antioxidant capacity and significantly increased serum malondialdehyde concentrations have been investigated, showing that they are related to episodes of bovine respiratory disease and mortality in calves (Chirase et al., 2004).

Hormonal regulation is essential to spermatogenesis, which is regulated by the hypothalamus-pituitary-testis axis, especially by follicle stimulating hormone (FSH) and luteinizing hormone (LH), which functionally connect the brain with the testis (Alves et al., 2013). Hormones exert their biological effects through binding with their receptors. The male carriers of homozygous mutation of the LHR gene display delayed puberty, micropenis, and oligospermia, so LHR mutations may be responsible for male hypogonadism with reduced spermatogenesis (Bruysters et al., 2008). Gonadotropins and androgen receptors (AR) play a role in gonadal development (Omran Nel, 2012), and FSH and testosterone are the main hormonal regulators of spermatogenesis (Sofikitis et al., 2008). Heat shock proteins (HSP) also play pivotal roles in spermatogenesis. HSP70 has been found to be present in the spermatozoa of mature bulls, and redistribution of the protein occurs during capacitation and the acrosome reaction (Kamaruddin et al., 2004). Significantly increased expression of HSP70 in infertile male may indicate that HSP70 is a protective protein against apoptosis in spermatozoa (Erata et al., 2008).

Transport stress first activates the hypothalamic-adrenal cortex and then sympatheticadrenal-medulla (Mitchell et al., 1988) and alters the concentrations of a series of hormones, such as CRH, GnRH, TH, and ACTH. Numerous studies have shown that stress-induced activation of the hypothalamic-pituitary-adrenal (HPA) axis plays an important role in inhibiting the hypothalamic-pituitary-gonadal (HPG) axis (Cevik et al., 2004; Chand and Lovejoy, 2011). Studies have suggested plasma cortisol levels and HSP70 as indicators of 
the transport stress. An elevation of LHR secretion has been observed during transport stress (Bieglmayer et al., 1980). The effect of transport stress on disease incidence, immune response, meat quality and also indicators of the extent of stress has been studied by many researchers. However, to date, there is little scientific literature with regard to the effect of transport stress on male reproduction performance. To elucidate the mechanisms of transport stress on male reproduction performance and further provide evidence for reducing or eliminating the harm it does to dairy industry, LHR, AR and HSP70 were selected as candidate genes to study their expression profiles through QPCR and Western blot after long-distance transport using mice as the animal model.

\section{MATERIAL AND METHODS}

\section{Studied animals}

All procedures involving animals were approved by the Animal Care and Use Committee of Huazhong Agricultural University. A total of 30 mature male Kunming mice between 9 and 10 weeks old were obtained from the Animal Experiment Centre of Wuhan University. All mice were conventionally fed 2 weeks prior to the experiment to facilitate their adaptation to the new environment. At the beginning of the experiment, the mice were randomly divided into control group and experimental group, with 15 mice in each group. The experimental group was transported approximately $1000 \mathrm{~km}$ (time, $15 \mathrm{~h}$ ) on a commercial road in November.

\section{Samples, body, and organ weight}

All animals including control group were sacrificed by cervical dislocation after one day's rest. Testis and epididymis samples were collected and weighed and organ indices were calculated according to the formula below:

$$
\text { Organ index }(\mathrm{mg} / 100 \mathrm{gwt})=\text { organ weight }(\mathrm{mg}) / \text { body weight }(\mathrm{g}) \times 100
$$

The testes for routine histology studies were fixed in $4 \%$ paraformaldehyde, while those for biochemical analysis were frozen in liquid nitrogen.

\section{Sperm count}

A small piece of the cauda epididymis of each animal was dissected and placed in $1 \mathrm{~mL}$ of $0.9 \%$ saline, and then cut it softly to make spermatozoa swim out into the medium. Sperm count was evaluated with a colorimeter (Ibersan, Portuguesa) according to manufacturer instructions.

\section{Histopathology}

Formalin-fixed, paraffin-embedded testes were serially cut into 5 - $\mu \mathrm{m}$ sections. Each section was routinely stained with hematoxylin and eosin and examined by light microscopy. 


\section{RNA extraction, reverse transcription, and quantitative real-time PCR}

Total RNA isolated from testes was prepared using Trizol reagent (Invitrogen, USA), and $2 \mu \mathrm{g}$ total RNA were then used for cDNA synthesis by SuperScript reverse transcriptase (Invitrogen, USA). cDNA ( $1 \mu \mathrm{L}$ ) was added to $20 \mu \mathrm{L}$ reaction mixture containing $10 \mu \mathrm{L}$ DyNAmo SYBR Green qPCR kit (FINNZYMES, USA) and $1 \mu \mathrm{L} 12.5 \mu \mathrm{M}$ primer (forward and reverse). Quantitative real-time PCR was carried out using the LightCycler ${ }^{\circledR} 480$ System (Roche, Basel, Switzerland) for cycles of $95^{\circ} \mathrm{C}$ for $30 \mathrm{~s}, 60^{\circ} \mathrm{C}$ for $1 \mathrm{~min}$, and $72^{\circ} \mathrm{C}$ for $1 \mathrm{~min}$. This was continued through 40 cycles. Primer pairs for quantitative RT-PCR are shown in Table 1.

\begin{tabular}{|c|c|c|c|}
\hline Genes & Primer sequence (5' to $\left.3^{\prime}\right)$ & Anneal temperature $\left({ }^{\circ} \mathrm{C}\right)$ & Product size (bp) \\
\hline$\overline{\text { LHR }}$ & $\begin{array}{l}\text { F: 5'-TAGAGAAGCGAATAACGAG-3' } \\
\text { R: 5'-AGGAGAACAAAGAGGACTG-3' }\end{array}$ & 60 & 231 \\
\hline $\mathrm{AR}$ & $\begin{array}{l}\text { F: 5'-GGAGGTTACGCCAAAGGATT-3' } \\
\text { R: 5'-GCCAGCGGAAAGTTGTAGTA-3' }\end{array}$ & 60 & 170 \\
\hline HSP70 & $\begin{array}{l}\text { F: 5'-GAAGGTGCTGGACAAGTGC-3' } \\
\text { R: 5'-GCCAGCAGAGGCCTCTAATC-3' }\end{array}$ & 60 & 237 \\
\hline$\beta$-actin & $\begin{array}{l}\text { F: 5'-GTATGCCTCGGTCGTACCA-3' } \\
\text { R: 5'-CTTCTGCATCCTGTCAGCAA-3' }\end{array}$ & 60 & 499 \\
\hline
\end{tabular}

\section{Western blotting}

Testis tissue explants were homogenized in $10 \mathrm{~mL}$ lysis buffer $(10 \%$ SDS in PBS containing protease inhibitors) and placed on ice for $2 \mathrm{~h}$ with vortexing every $10 \mathrm{~min}$. Samples were centrifuged at $12000 \mathrm{~g}$ for $30 \mathrm{~min}$. Total protein concentration was determined by the BCA assay (Pierce, Rockford, USA), and $50 \mu \mathrm{g}$ total protein were subjected to gel electrophoresis. Proteins were separated on a $12 \%$ polyacrylamide gel and transferred to PVDF membranes (Millipore, Bedford, MA). Membranes were first blocked with Trisbuffered saline (TBS) containing 5\% skimmed milk for $1 \mathrm{~h}$ and washed with TBS three times (10 min each), and the membranes were then incubated overnight at $4^{\circ} \mathrm{C}$ with primary antibody. Anti-HSP70, anti-LHR and anti-androgen receptor (Boster, Beijing) were used for primary antibody. After incubation with the primary antibody, membranes were washed three times with PBS containing 0.1\% Tween 20, incubated for $1 \mathrm{~h}$ at room temperature with 3000-fold diluted HRP labeled goat anti-rabbit secondary antibodies, and washed three times with PBS containing $0.1 \%$ Tween 20 (10 min each). Signal was detected using an ECL kit (CWBIO, Beijing, China). The band intensities were measured with the AlphaEaseFC software (Alpha Innotech, USA).

\section{Statistical analysis}

The significance of differences between each group was conducted by one-way analysis of variance (ANOVA) using the SAS 9.0 software. Comparison of the mean value of the transport group with that of control group was carried out using the Duncan test for multiple comparisons. 


\section{RESULTS}

\section{Body and organ weight, sperm count}

The body and organ weights of the sacrificed mice were examined (Table 2). There was a statistically significant reduction in average body weight in the transport group. Considering organ weights, there were no significant differences between the two groups, but the epididymis index increased significantly in the transport group. Considering the concentration of sperm in the epididymis, a significantly decreased sperm concentration was observed with transport.

Table 2. Effect of transportation stress on body weight, organ weight organ index, and sperm count.

\begin{tabular}{lccccccc}
\hline & $\mathrm{N}$ & Body weight & Testis weight & Epididymis weight & Testis index & Epididymis index & Sperm count \\
\hline Control & 9 & $34.34 \pm 3.14$ & $141.01 \pm 316.80$ & $40.978 \pm 4.86$ & $411.02 \pm 88.27$ & $119.46 \pm 10.57$ & $17.75 \pm 3.96$ \\
Stress & 9 & $31.50 \pm 1.63^{*}$ & $140.11 \pm 19.78$ & $40.93 \pm 4.60$ & $445.04 \pm 61.04$ & $130.01 \pm 13.26^{*}$ & $10.58 \pm 4.27^{*}$ \\
\hline
\end{tabular}

Data reported are means \pm SD.

\section{Histology of testes}

Histological analysis showed that a reduction in seminiferous epithelium thickness in the transported mice (Figure 1).
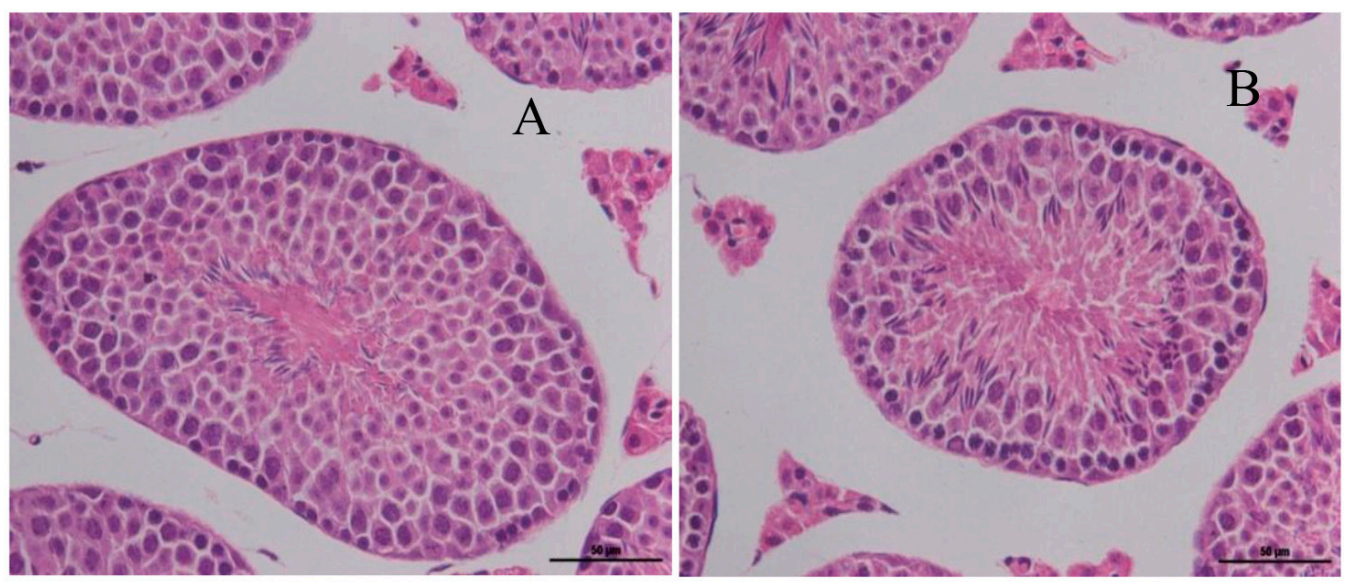

Figure 1. Representative image of histological sections of the seminiferous tubules in adult male mice. A. control group with no treatment; $\mathbf{B}$. transportation group.

\section{Expression of LHR, AR, and HSP70 in the testes of mice}

mRNA and protein expression levels of LHR, AR, and HSP70, normalized to $\beta$-actin, in the testes of transported mice and control mice are shown in Figures 2 and 3. 


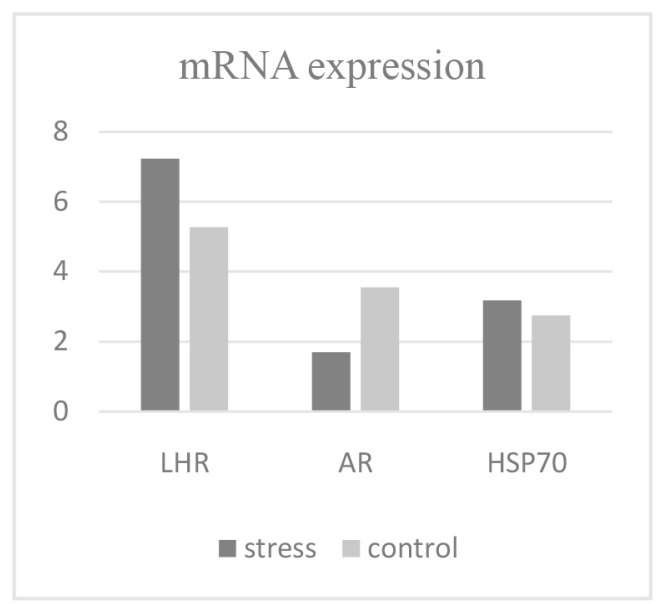

Figure 2. Expression profiles of LHR, AR, and HSP70 in mice subjected to transportation stress. Gene expression changes were measured by qRT-PCR.

a

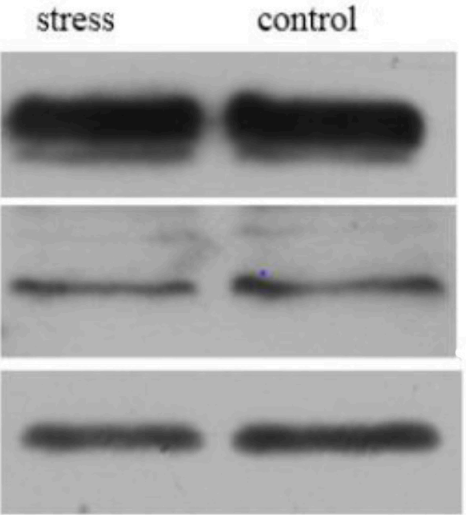

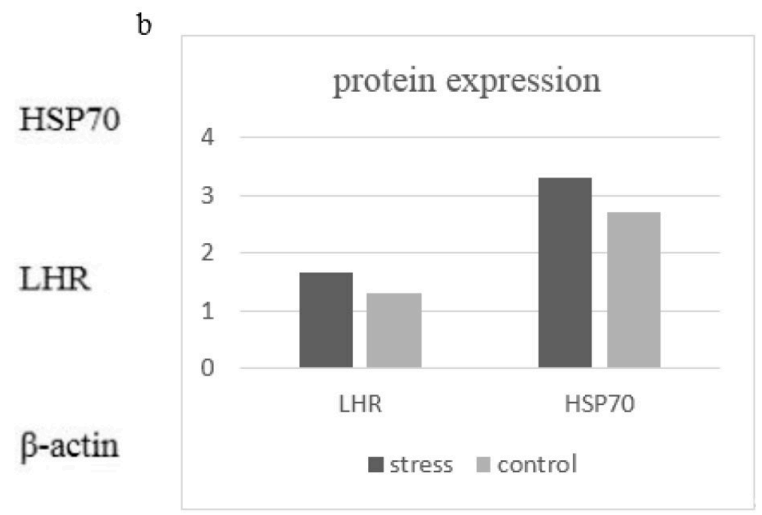

Figure 3. Western blot analysis (a) and protein expression levels of HSP70 and LHR in the testes of transported mice and control mice. (b) Comparison of HSP70 and LHR relative expression between the transported and the control group (means $\pm \mathrm{SD}$ ). The relative protein content was the ratio of the gray scale of the target protein band $v s$ the gray scale of the $\beta$-actin band.

The mRNA expression levels of LHR and HSP70 in the testes of the transported mice were slightly higher than that of control mice $(\mathrm{P}>0.05)$; however, they did not reach significant levels (Figure 2). Expression levels of AR decreased significantly after transport (Figure 2).

The levels of protein expression of LHR and HSP70 in the testes of the transported mice displayed a similar tendency as those of mRNA expression (Figure 3). The levels of LHR and HSP70 in the testes of the transported mice increased slightly after transportation. However, none of the changes were statistically significant compared with the control mice. 


\section{DISCUSSION}

Spermatogenesis, as a complex of precisely regulated intracellular events, is affected by many factors, which include genetics and environment. A significant lower total sperm count was found in motorway tollgate workers compared with normal control (Calogero et al., 2011). Transport, especially long road transport, will cause serious stress to animals. The result of our present study also showed a significant reduction in sperm count in transported mice, the conditions of which are similar to those of motorway tollgate workers. Genetics is also an important factor that influences spermatogenesis and sperm quality. In another of our studies, we found that different genotypes of LHR had a significant effect on sperm density and fresh sperm motility, where the SNP site was located in an intron (Sun et al., 2012).

Plasma cortisol concentrations had a negative correlation with plasma dehydroepiandrosterone $(\mathrm{r}=-0.55, \mathrm{P}=0.001)$ and testosterone $(\mathrm{r}=-0.43, \mathrm{P}=0.02)$, while positively correlating with progesterone $(\mathrm{r}=0.59, \mathrm{P}=0.0007)$ during transportation stress in beef bulls (Sporer et al., 2008). Many researchers have considered plasma cortisol as an indicator of stress, and have found a significant increase in plasma cortisol concentration (Tischner and Niezgoda, 2000; Leche et al., 2013). In our study, a significant reduction of AR expression was found in transported mice, and this may indicate that Sertoli cells function changed greatly in the testis, but the complex mechanism is still unknown. One reason for this maybe the reduction in androgens controlling the expression of AR at the transcriptional level, posttranscriptional level and protein level (Lee and Chang, 2003). Abnormalities in the androgen-AR signaling pathway further affect the proper function of male reproductive system, as in male infertility. A dramatic decrease in AR expression was also found after heat treatment in another study (Chen et al., 2008), the result of which is consistent with our research. The lack of AR in Sertoli cells or Leydig cells would result in the arrest of spermatogenesis; however, the deletion of AR gene in mouse germ cells does not affect spermatogenesis and male fertility (Wang et al., 2009).

LHR expression in our present study was slightly higher in the testes of transported mice compared with control mice. The results of our present study did not conflict with our previous research, because many researchers have confirmed that the SNPs in introns can affect gene expression, phenotype and consequently function (Spotter et al., 2010; Stinckens et al., 2010). HSP70 may play an important role in spermatogenesis and sperm maturation (Cao et al., 2009). In our present study, a slight increase in HSP70 in transported mice was observed. The increased HSP70 expression may be a protective mechanism against apoptosis in spermatozoa (Erata et al., 2008).

In summary, the results of our present study indicated that long road transport had an adverse effect on reproductive organs and spermatozoa in adult males.

\section{Conflicts of interest}

The authors declare no conflict of interest.

\section{ACKNOWLEDGMENTS}

Research supported by the Earmarked Fund for the Modern Agro-Industry Technology Research System of China (\#CARS-37-04B), the Special Fund for Agro Scientific Research in 
the Public Interest (\#201003060), the Sino-UK Cooperation Key Program (\#S2010GR0947), and the National Basic Research Program of China (“973” Program) (\#2012CB518801).

\section{REFERENCES}

Alves MG, Rato L, Carvalho RA, Moreira PI, et al. (2013). Hormonal control of Sertoli cell metabolism regulates spermatogenesis. Cell Mol. Life Sci. 70: 777-793.

Bieglmayer C, Spona J, Adamiker D and Jettmar W (1980). Basal and LH-RH-stimulated gonadotropin release after transport stress in male rats. Endokrinologie 75: 304-310.

Bruysters M, Christin-Maitre S, Verhoef-Post M, Sultan C, et al. (2008). A new LH receptor splice mutation responsible for male hypogonadism with subnormal sperm production in the propositus, and infertility with regular cycles in an affected sister. Hum. Reprod. 23: 1917-1923.

Calogero AE, La Vignera S, Condorelli RA, Perdichizzi A, et al. (2011). Environmental car exhaust pollution damages human sperm chromatin and DNA. J. Endocrinol. Invest. 34: e139-e143.

Cao W, Huang P, Zhang L, Wu HZ, et al. (2009). Acute heat stress increases HSP70 expression in the testis, epididymis and vas deferens of adult male mice. Zhonghua Nan Ke Xue 15: 200-206.

Cevik R, Gur A, Acar S, Nas K, et al. (2004). Hypothalamic-pituitary-gonadal axis hormones and cortisol in both menstrual phases of women with chronic fatigue syndrome and effect of depressive mood on these hormones. $B M C$ Musculoskelet. Disord. 5: 47.

Chand D and Lovejoy DA (2011) Stress and reproduction: controversies and challenges. Gen. Comp. Endocrinol. 171: 253-257.

Chen M, Cai H, Yang JL, Lu CL, et al. (2008). Effect of heat stress on expression of junction-associated molecules and upstream factors androgen receptor and Wilms' tumor 1 in monkey sertoli cells. Endocrinology 149: 4871-4882.

Chirase NK, Greene LW, Purdy CW, Loan RW, et al. (2004). Effect of transport stress on respiratory disease, serum antioxidant status, and serum concentrations of lipid peroxidation biomarkers in beef cattle. Am. J. Vet. Res. 65: 860-864

Erata GO, Kocak Toker N, Durlanik O, Kadioglu A, et al. (2008). The role of heat shock protein 70 (Hsp 70) in male infertility: is it a line of defense against sperm DNA fragmentation? Fertil. Steril. 90: 322-327.

Gonzalez LA, Schwartzkopf-Genswein KS, Bryan M, Silasi R, et al. (2012). Factors affecting body weight loss during commercial long haul transport of cattle in North America. J. Anim. Sci. 90: 3630-3639.

Greer T, Schwartzkopf-Genswein K, Crowe T and Gonzalez LA (2011). The effect of transport distance on cattle liner microclimate, live weight loss and carcass quality of finished heifers during summer transport. Can. J. Anim. Sci. 91: $512-512$

Hoffman LC and Fisher P (2010). Comparison of the effects of different transport conditions and lairage times in a Mediterranean climate in South Africa on the meat quality of commercially crossbred Large white $\mathrm{x}$ Landrace pigs. J S Afr. Vet. Assoc. 81: 224-227.

Honkavaara M, Rintasalo E, Ylonen J and Pudas T (2003). Meat quality and transport stress of cattle. Dtsch Tierarztl. Wochenschr. 110: 125-128.

Kamaruddin M, Kroetsch T, Basrur PK, Hansen PJ, et al. (2004). Immunolocalization of heat shock protein 70 in bovine spermatozoa. Andrologia 36: 327-334.

Leche A, Della Costa NS, Hansen C, Navarro JL, et al. (2013). Corticosterone stress response of Greater Rhea (Rhea americana) during short-term road transport. Poult. Sci. 92: 60-63.

Lee DK and Chang C (2003). Endocrine mechanisms of disease: Expression and degradation of androgen receptor: mechanism and clinical implication. J. Clin. Endocrinol. Metab. 88: 4043-4054.

Lv Q, Zhang S and Zhao R (2011). Transportation stress alters the expression of immunoregulatory cytokines in the porcine thymus. Vet. J. 187: 229-233.

Mitchell G, Hattingh J and Ganhao M (1988). Stress in cattle assessed after handling, after transport and after slaughter. Vet. Rec. 123: 201-205.

Omran Nel S (2012). Testosterone, gonadotropins and androgen receptor during spermatogenesis of Biomphalaria alexandrina snails (Pulmonata: Basommatophora). Reprod. Biol. 12: 301-308.

Riondato F, D'Angelo A, Miniscalco B, Bellino C and Guglielmino R (2008). Effects of road transportation on lymphocyte subsets in calves. Vet. J. 175: 364-368.

Smiecinska K, Denaburski J and Sobotka W (2011). Slaughter value, meat quality, creatine kinase activity and cortisol levels in the blood serum of growing-finishing pigs slaughtered immediately after transport and after a rest period. Pol. J. Vet. Sci. 14: 47-54. 
Sofikitis N, Giotitsas N, Tsounapi P, Baltogiannis D, Giannakis D, et al. (2008). Hormonal regulation of spermatogenesis and spermiogenesis. J. Steroid. Biochem. Mol. Biol. 109: 323-330.

Sotiraki ST, Leontides LS and Himonas CA (1999). The effect of transportation and confinement stress on egg production by Dicrocoelium dendriticum in sheep. J. Helminthol. 73: 337-339.

Sporer KR, Xiao L, Tempelman RJ, Burton JL, Earley B, et al. (2008). Transportation stress alters the circulating steroid environment and neutrophil gene expression in beef bulls. Vet. Immunol. Immunopathol. 121: 300-320.

Spotter A, Hamann H, Muller S and Distl O (2010). Effect of polymorphisms in four candidate genes for fertility on litter size in a German pig line. Reprod. Domest. Anim. 45: 579-584.

Stinckens A, Mathur P, Janssens S, Bruggeman V, Onagbesan OM, et al. (2010). Indirect effect of IGF2 intron3 g.3072G $>$ A mutation on prolificacy in sows. Anim. Genet. 41: 493-498.

Sun LP, Du QZ, Song YP, Yu JN, Wang SJ, et al. (2012). Polymorphisms in luteinizing hormone receptor and hypothalamic gonadotropin-releasing hormone genes and their effects on sperm quality traits in Chinese Holstein bulls. Mol. Biol. Rep. 39: 7117-7123.

Tischner M Jr. and Niezgoda J (2000). Effect of transport on the intensity of stress reactions in mares and foals. J. Reprod. Fertil. Suppl. 725-730.

Wang RS, Yeh S, Tzeng CR and Chang C (2009). Androgen receptor roles in spermatogenesis and fertility: lessons from testicular cell-specific androgen receptor knockout mice. Endocr. Rev. 30: 119-132. 